Article

\title{
Eco-Industrial Park (EIP) Development in Viet Nam: Results and Key Insights from UNIDO's EIP Project (2014-2019)
}

\author{
Jérôme Stucki ${ }^{1}$, Alessandro Flammini ${ }^{1, *}$, Dick van Beers ${ }^{1}$, Tran Thanh Phuong ${ }^{1}$, \\ Nguyen Tram Anh ${ }^{1}$, Tran Duy Dong ${ }^{2}$, Vu Quoc Huy ${ }^{2}$ and Vuong Thi Minh Hieu ${ }^{2}$ \\ 1 United Nations Industrial Development Organization, Department of Environment (UNIDO), \\ Industrial Resource Efficiency Division, Vienna International Centre, 1400 Vienna, Austria \\ 2 Ministry of Planning and Investment (MPI), Department of Economic Zones Management, Hanoi 100803, \\ Viet Nam \\ * Correspondence: A.FLAMMINI@unido.org
}

Received: 26 June 2019; Accepted: 20 August 2019; Published: 27 August 2019

check for updates

\begin{abstract}
Industrial parks have been promoted as cornerstone strategies for economic development in countries around the world, including Viet Nam. The transformation of conventional industrial zones (IZs) into eco-industrial parks (EIPs) presents an effective opportunity to attain inclusive and sustainable industrial development, as well as increasing the economic competitiveness and resilience of industrial parks. This paper presents and discusses the interventions, key results, and lessons learned from the Ministry of Planning and Investment (MPI) and UNIDO's work on EIPs in Viet Nam as part of the Project "Implementation of eco-industrial park initiative for sustainable industrial zones in Viet Nam". The Project was undertaken with the objective of developing policies and guidelines to facilitate the transformation of industrial zones into eco-industrial parks and implementing EIP principles in five existing industrial zones in the provinces of Da Nang (Hoa Khanh IZ), Can Tho (Tra Noc 1 and 2 IZs), and Ninh Binh (Khanh Phu IZ and Gian Khau IZ), which serve as pilots to support replication and upscaling across Viet Nam. The application of the Project's policy, company, and park-level interventions demonstrated their value in contributing to the development and implementation of EIP practices in the country. Rather than stand-alone solutions, multi-disciplinary EIP concepts are most effective if applied as part of an integrated top-down approach (policy support as entry point for interventions) combined with a bottom-up approach (industrial park as entry point). The issuance of Decree 82/2018/ND-CP on the management of industrial parks and economic zones is a new policy outlining the requirements and process for transforming industrial zones into EIPs. The Decree is thereby an important driver for EIP development. Legal challenges with regards to EIPs still exist, including the lack of available and reliable data and the need for detailed standards and guidelines on reusing by-products, wastes, and wastewater. The final adoption of minimum EIP requirements in Viet Nam for social, economic, and environmental aspects is a key issue for scaling up implementation. The work undertaken as part of the Project will continue through the Global EIP Programme, in which Viet Nam is one of the participating countries.
\end{abstract}

Keywords: eco-industrial parks; sustainable industrial development; industrial zones; policy development; cleaner production; industrial symbiosis; industrial synergies; Viet Nam

\section{Introduction}

The EIP concept and approach have evolved over time to address interrelated aspects, including, for example: resource efficient and cleaner production (RECP); industrial symbiosis; climate change; pollution; social standards; shared infrastructure; improved spatial zoning; and management. 
Different terminologies and definitions are used around the world to refer to eco-industrial parks and related concepts (e.g., sustainable industrial zones, green manufacturing clusters) [1-9]. In general, all definitions refer to a number of companies located in a defined area and all definitions share many similarities, opportunities, and challenges in the path to sustainable industrial development.

Having a formalized and well-functioning zone/park management structure is a key requisite for any EIP $[6,10,11]$. Park management assists EIPs and their tenant companies to take advantage of opportunities associated with RECP, industrial symbiosis, integration with local community and natural environment, spatial planning/zoning, and park level infrastructure and utility services. Although the focus of this paper is on existing industrial parks, the EIP concept is relevant to retrofit and optimize existing industrial parks (brownfields) as well as to guide the sustainable planning and development of new industrial parks (greenfields) [11-13].

Article 2 of Decree 82/2018/ND-CP [14] defines EIPs for the purposes of Vietnamese laws and government policies as follows: "Eco-industrial park means an industrial park in which enterprises get involved in cleaner production, make effective use of natural resources and enter into manufacturing cooperation and affiliation in order to tighten industrial symbiosis to promote economic, environmental and social efficiency in these enterprises." This is in line with the EIP definition commonly applied internationally $[6,10]$ which recognizes the importance of the three pillars of sustainable development (economic, environmental, social) and of integrating EIP considerations into all phases of the development and operations of industrial parks.

International good practices illustrate that the types of economic, environmental, and social benefits from EIPs vary significantly, going well beyond the conventional business case benefits $[8,15,16]$. The benefits are not only commercial but also strategic, leading to reduced exposure to risk, increased competitiveness, business development, production continuity, and an improved reputation among key stakeholders. By working together, the business community works toward collective benefits greater than the combined benefits of each company [17-20].

This paper presents and discusses the interventions and key results from MPI and UNIDO's work, as the specialized UN agency dealing with sustainable industrial development, on EIPs in Viet Nam as part of the Project "Implementation of eco-industrial park initiative for sustainable industrial zones in Viet Nam" (hereafter referred to as "the Project"'). The paper also provides lessons learned and insights to guide future EIP interventions in the country and the region, distilling them to support replication and upscaling efforts. The Project was undertaken from October 2014 to June 2019 with the objective of developing policies and guidelines to facilitate the transformation of IZs into EIPs and implementing EIP principles in existing IZs. Five IZs were selected to launch EIP pilot projects, namely Khanh Phu IZ and Gian Khau IZ (Ninh Binh), Hoa Khanh IZ (Da Nang) and Tra Noc 1 and 2 IZs (Can Tho).

\section{Country Context}

\subsection{Challenges}

Over the past decade Viet Nam has experienced rapid economic growth driven mainly by the processing and manufacturing sectors. Industrial zones (including industrial parks, special economic zones, EIPs, technology parks, and innovation districts) have been promoted as cornerstone strategies for the economic development in countries around the world, including Viet Nam. To facilitate the establishment of new industries, the Government created industrial zones (IZs), which now account for $38 \%$ of the country's GDP [21]. However, industrial activities have also had negative repercussions for the environment and for human health. Inefficient management of resources has increased greenhouse gas (GHG) emissions and has caused water and soil pollution. The transformation of conventional industrial parks into EIPs presents an effective opportunity to attain inclusive and sustainable industrial development and to meet the objectives of the 2030 Agenda and the Sustainable Development Goals (SDGs). 
Viet Nam is one of the most energy-intensive countries in East Asia, with the energy consumption tripling over the past decade. Industrial growth has been one of the key drivers of Viet Nam's increasing energy intensity, accounting for $48 \%$ or almost half of the energy use. By 2030, Viet Nam's overall GHG emissions are expected to increase five-fold, per capita emissions four-fold, and the carbon intensity of GDP by $20 \%$. Rapid industrialization in coastal areas has contributed to the deterioration of coastal water quality. Around $70 \%$ of the total industrial effluent is generated in IZs, most of which (around 1 million $\mathrm{m}^{3} /$ day) is discharged directly and is untreated [21]. At present the collection, transportation, recycling, or reuse of the increasing amounts of solid waste from industrial zones is insufficient, with hazardous waste accounting for around $20 \%$ of the total [22].

Although there are many polices encouraging sustainable industry development [23-25], the challenges facing IZs in Viet Nam are manifold. A large number of industrial enterprises do not consider energy efficiency a priority because of a lack of awareness of the potential savings and of the available technologies. They tend to carry out minimal or low-cost energy efficiency measures, while focusing on the capacity expansion to modernize their operations and improve competitiveness and profitability. There is a lack of knowledge among company managers, local engineering personnel, and local technology suppliers with regard to the available clean and low-carbon technologies, appropriate practices within the operation, and process optimization strategies. In addition, there is a lack of awareness of alternative financial sources for investments in environmentally friendly technologies, for instance from the Swiss Green Credit Trust Fund or the Viet Nam Environment Protection Fund. Overall, there is a low level of enforcement of environmental legislation as a result of bottlenecks in personnel and supporting resources (e.g., monitoring equipment), while the level of responsibility among authorities and expertise from IZ management boards is unclear. There is also a lack of framework conditions and guidelines for the transformation of IZ into eco-industrial parks.

At present, the policy framework for the transition to the EIP model in Viet Nam is both insufficient and inconsistent. There are many agencies in charge of state management for IPs and there is a lack of effective inter-agency coordination. At the same time, the decentralization mechanisms are unclear, meaning that IZ management boards in each locality operate according to different models, with different functions, tasks, and powers. There are a number of social policies for employees in IZs, however these are not focused and, in practice, not very effective. In addition, insufficient attention has been paid to date for the creation of connections between IZs and the local community [26].

One key challenge from a policy perspective is that the current regulatory framework in Viet Nam does not encourage reusing wastewater and industrial by-products between companies. No detailed guidance is currently available on how to obtain government approval for their reuse, resulting in lengthy processes and random results. This is expected to change with Decree 82/2018/ND-CP 'Management of Industrial Parks and Economic Zones', which was approved in May 2018 and which prescribes the planning, establishment and operation of, policies on, and state management of, industrial parks and economic zones.

\subsection{Drivers for Eco-Industrial Parks in Viet Nam}

While challenges exist, there are substantial drivers for the transformation of traditional industrial zones into EIPs. Key drivers include reducing an industrial park's environmental footprint and associated costs; promoting efficiency gains and resulting economic savings; enabling community cohesion; providing better access to finance and technical support; and enhancing business competitiveness. In short, EIPs are about creating better and smarter designed industrial parks with are more competitive and more resilient to economic, environmental, and social risks.

Increased business competitiveness is one of the most significant drivers for the development of EIPs optimizing resource consumption in companies with the result of reducing energy, water, and material consumption in order to reduce cost and increase competitiveness. Besides, industries that operate in well-designed and well-managed parks can take advantage of resource efficiencies, reductions in waste disposal, value-addition and risk-mitigation, as well as of other available services, 
leading to cost savings. The indirect benefits of EIPs can be more difficult to quantify but are crucial to the long-term economic sustainability of the park. These include indirect employment creation through skills upgrading and training, technology transfer, improved reputation, and increased incidence of the "demonstration effect" arising from the application of best practice, leading to wider uptake of more efficient practices, especially in attracting foreign direct investments.

The environmental benefits of EIPs include reduced levels of pollution and GHG emission savings because of more efficient use of resources (raw materials, water, energy) and the reduction, reuse, and recycling of wastes, which can contribute to the preservation and protection of local biodiversity. Additionally, improved management of chemical and hazardous substances in EIPs can lead to additional environmental benefits and greater worker safety.

The social benefits deriving from EIP activities can catalyze the creation of quality local jobs through better working conditions. EIPs also work to enhance local community well-being through better community outreach, with some EIPs working toward increased rates of gender equality, through for instance the creation of employment for women and dedicated facilities for female workers. Better security features help to mitigate crime, creating a greater sense of security for workers. EIPs often support surrounding communities, through the creation of a social infrastructure such as vocational training centers, offering skills development training, as well as the provision of broader community services.

Government agencies have created IZs to facilitate the establishment of new industries with the provision of infrastructure such as utility, water and effluent treatment. As of 2018, a total of 328 IZs, out of which 230 in operation, were located in 56 Vietnamese provinces. The economic value of IZs for Viet Nam is substantial, with total turnover exceeding USD 165 billion, increasing by around 15\% year-on-year. The total export sales stood at close to USD 119 billion, comprising 55\% of the total export figure for Viet Nam. As of the end of 2017, the total employment in industrial parks nationwide was 3.12 million [22,27]. The rapid historical development of the number and size of industrial parks in Viet Nam is presented in Figure 1.

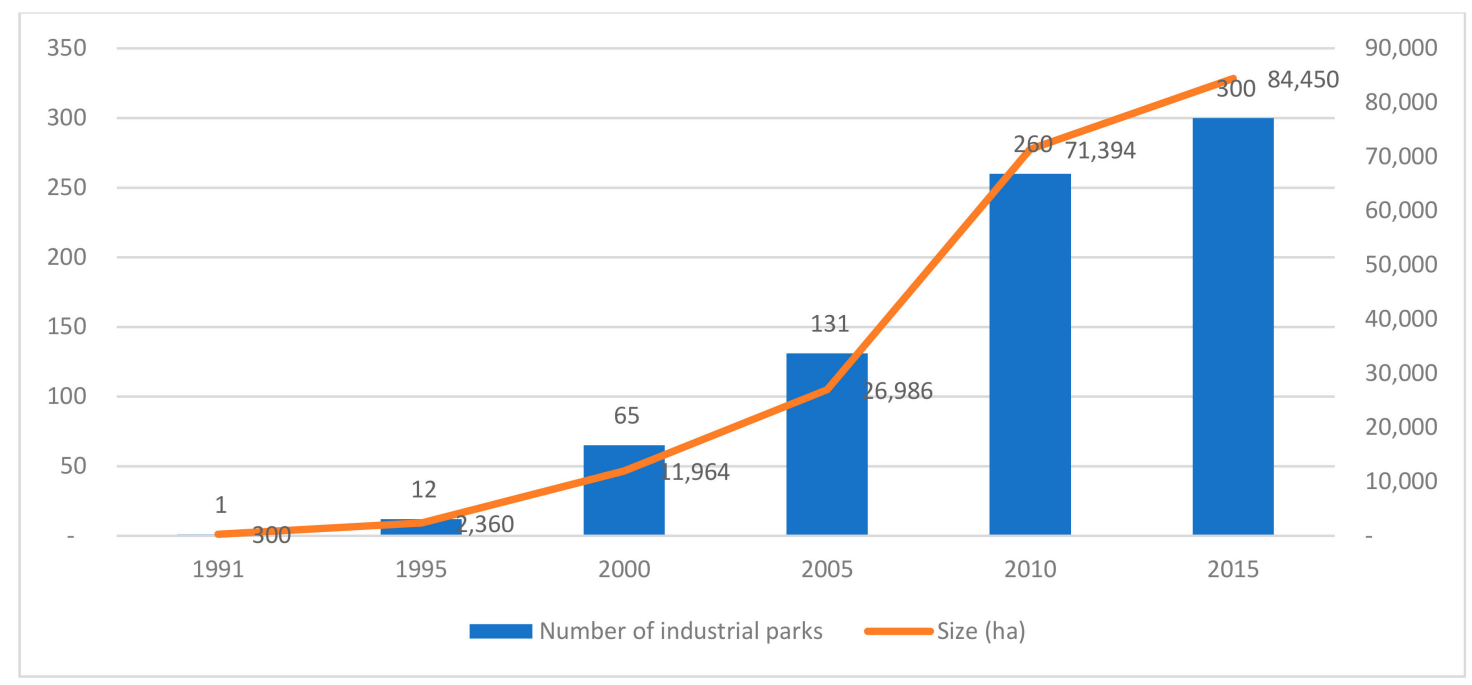

Figure 1. Number and size of industrial parks in Viet Nam [28].

It is the Government's viewpoint that IZs should develop sustainably with serious attention to environment and social issues. The development of IZs should contribute to the successful implementation of the Socio-Economic Development Strategy of 2015-2020 and the Green Growth Strategy. Cleaner production and EIPs are the two important and recognized tools for providing solutions toward sustainable production in Viet Nam [29]. 


\section{Materials and Methods}

The approach applied by the Project is presented in Figure 2, which involved several stakeholders including the MPI, provincial authorities, park management, tenant companies, and other ministries and national agencies, covering both bottom-up (e.g., EIP pilot projects, capacity building for IZ, and tenant companies) and top-down approaches (e.g., development of policy and guidelines, capacity building for government agencies).

The following sections of this paper outline the Project's interventions, key results, and lessons learned. Detailed information about the Project's approaches and methodologies is available from: https://eipvn.org/ and [22].

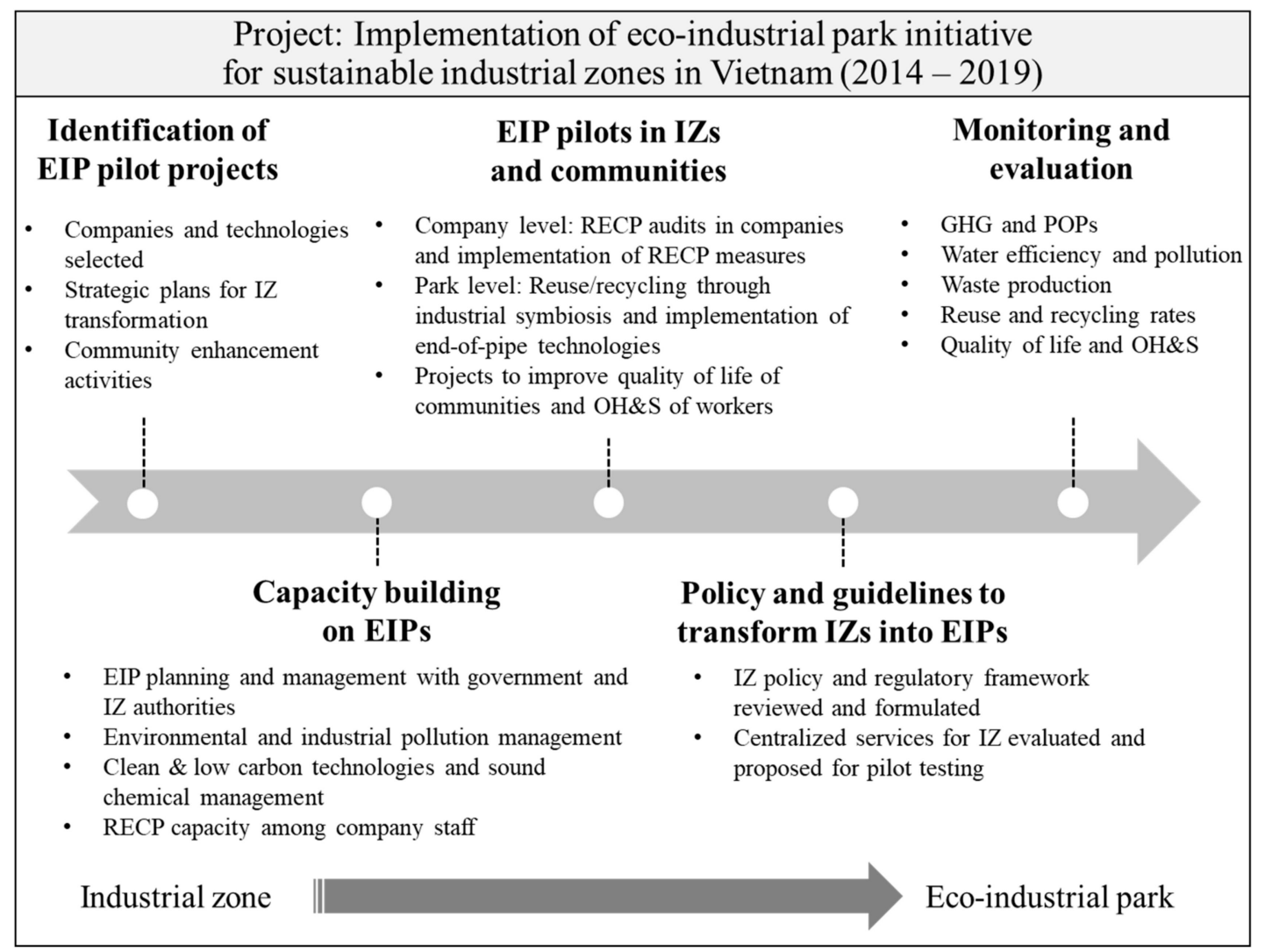

Figure 2. Project methodology (based on [22]).

Following the methodology presented in Figure 2 above, the Project's interventions can be grouped in three main categories:

- Policy development: UNIDO and the World Bank Group have been supporting the MPI in developing technical EIP guidelines (launched in July 2018) with the approved Decree 82, including support to operationalize the Decree, e.g., through International Expert Group meetings [26,30-32]. Other policy interventions undertaken as part of the Project cover a review of existing legislative and institutional frameworks of industrial parks toward the development of EIPs [8], the formulation of standards requirements, and a roadmap for developing eco-industrial parks [26,31,33], and EIP related topic trainings and awareness raising workshops.

- Company interventions: Resource Efficient and Cleaner Production (RECP) entails the continuous improvement of processes, products, and services in order to increase efficiency and reduce risks to humans and the environment. RECP addresses the three sustainability dimensions in a synergistic manner: (a) Heightened economic performance through improved productive use of resources; (b) environmental protection through conservation of resources and minimization 
the industry's impact on the natural environment; and (c) social enhancement by providing jobs and protecting the well-being of workers and local communities [34,35]. As part of the Project, RECP assessments were undertaken with companies located in the pilot industrial parks. These assessments covered staff trainings, site visits to assess the production process, identification of opportunities, (pre)feasibility studies, and implementation of feasible options.

- Park level interventions: A key focus of the park level interventions of the Project was to identify and support the implementation of industrial symbioses in the pilot industrial parks participating in the Project (e.g., Khánh Phú IZ, Hòa Khánh IZ, and Trà Nóc 1\&2 IZ). Industrial symbiosis engages traditionally separate industries in a collective approach to competitive advantage involving physical exchange of materials, energy, water, and/or by-products [36]. Industrial symbiosis often deals with the use of a previously disposed waste (as solid, liquid, gas) from one facility by another facility to provide a valuable by-product.

\section{Results}

\subsection{Results_Policy Development}

As a regulator, MPI is the ministry responsible for overseeing the development of EIPs in Viet $\mathrm{Nam}$. In the past, there have been no formal policies, regulations, or guidelines for the development of EIPs in the country. To bridge this gap, the Government of Viet Nam issued Decree No.82/2018/ND-CP ("Decree 82"), dated 22 May 2018 [14], to regulate the management of IZs and economic zones. The Decree is applied to regulatory bodies, organizations, and individuals involved in investment and business activities in industrial parks and economic zones. It prescribes the minimum requirements, incentives, and institutional framework for EIPs in Viet Nam, as well as a framework for EIPs focusing on the potential conversion of existing industrial parks into EIPs.

The Project supported the national policy dialogues and contributed to the drafting of the above mentioned Decree 82, which was finalized by MPI in collaboration with other ministries (e.g., MONRE, MOST, MOF).

The national technical EIP guidelines [32,37] developed provide a mechanism to operationalize the development of EIPs in Viet Nam and its institutional framework in more than 300 IZs across the country with a focus on the environment. The guidelines detail the process to be recognized as an EIP, as well as the roles and responsibilities of different stakeholders in enabling the transformation of existing industrial parks into EIPs. The MPI, UNIDO, and the World Bank Group engaged a number of stakeholder groups to assist the Government in developing and pilot-testing the national EIP guidelines, similar in effect to a national framework [32,38]. Regulators and governmental institutions, industrial park managers, and participating enterprises were all integrated into the stakeholder engagement process. The International EIP Framework [11] was a fundamental factor in facilitating the alignment of the main international organizations working on EIP development, as was the national framework on EIPs in Viet Nam (see Figure 3).

Subsequently, UNIDO has been supporting MPI with the development of economic and social indicators [31] that complement the environmental indicators developed with the support of the IFC. This set of indicators, in line with the International EIP Framework, has been developed through a national consultation process and the indicators chosen according to their relevance, practicality, and scientific basis.

A handbook on prevention, preparedness, and response to environmental accidents from IZs [39] and a compilation of relevant policy documents to support communities living close to IPs [40] was produced by the Project to support the development of a National EIP Framework.

The main objective of the National EIP Framework (Figure 3) is the potential conversion of existing industrial zones into EIPs. It was developed as a means to assist the implementation of EIPs in practice, and to supplement the new legal framework on industrial parks and economic zones, which plans to introduce the new types of economic zones, including EIPs. The EIP framework provides an overview 
of the requirements, roles, and responsibilities of the different stakeholders, primarily, regulators and government institutions, industrial park developers, and participating enterprises in establishing EIPs and further contributing to their development. The EIP framework in Viet Nam includes a number of stakeholders. The industrial park developers and the tenants participating in the EIP programme (participating enterprises) are the main beneficiaries.

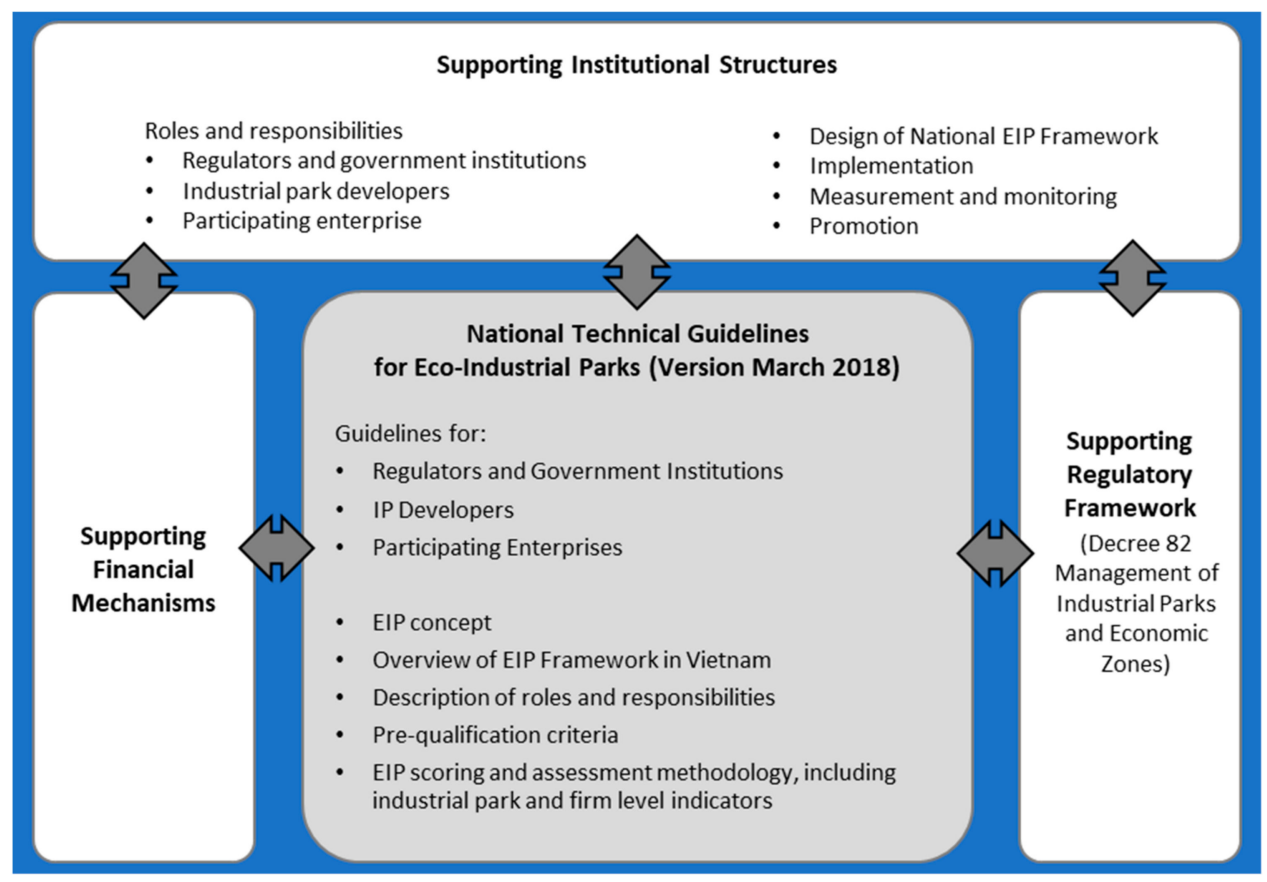

Figure 3. National eco-industrial parks framework for Viet Nam.

\subsection{Results-Company Interventions}

The Project worked with 73 companies located in the five pilot industrial parks to adopt RECP practices and technologies. Each company underwent an eight-month RECP assessment cycle, in which the company worked with experts to identify wasteful issues in their production process and to propose customized RECP options to tackle inefficiencies. These included opportunities to optimize inputs of raw materials, energy and water, as well as chemical safety and waste management. An RECP monitoring cycle was also conducted for the beneficiary companies, in order to verify the implementation of the RECO options. Along with in-company RECP assessments, the Project's company-level interventions involved capacity-building activities aiming to enhance the RECP implementation capability of company staff and national experts [41].

The benefits from the RECP assessments undertaken with companies in the five industrial parks are summarized in Table 1 and Figure 4. Initially more than one thousand RECP options were found, and these were consolidated in 680 concrete and practical RECP options by the Project, of which 546 were already implemented in 57 companies. The RECP options implemented to date delivered substantial savings, including reductions in the use of electricity $(19,274$ MWh per year) and fossil fuels (142 TJ per year), reduction in greenhouse gas emissions (30,570 $\mathrm{tCO}_{2}$-eq per year), water $\left(606,816 \mathrm{~m}^{3}\right.$ per year), and savings in the use of materials/chemicals (3121 $\mathrm{t}$ per year). The RECP options resulted in financial savings of EUR 2.9 million per year with an average payback time of 7 to 8 months. Almost EUR 10 million were mobilized by the Project from the recipient companies alone. These savings are the direct result from the Project's interventions and these do not include replication impacts. Materials saving options were implemented to help companies recycle and reuse by-products as materials in the production process, contributing to a reduction in the materials to be discharged into the environment. In addition, the process modification also helped to optimize the 
used materials. RECP options on chemicals mainly referred to process and technology modification to reduce the quantity of chemicals released into the environment and to improve product quality.

Table 1. Summary of benefits from company level interventions in the period 2016-2018 (as of May 2019).

\begin{tabular}{ccccc}
\hline & Ninh Binh & Da Nang & Can Tho & Total \\
\hline Investment (Euro) & $4,101,465$ & $2,857,108$ & $2,905,877$ & $9,864,450$ \\
Benefit (Euro) & $2,014,587$ & $1,747,193$ & $4,824,279$ & $8,586,058$ \\
Raw material (ton) & 443 & 8177 & 744 & 9363 \\
Electricity (kWh) & $9,347,734$ & $9,802,470$ & $38,674,662$ & $57,824,866$ \\
Fresh water (m ${ }^{3}$ ) & 37,145 & 298,467 & $1,130,348$ & $1,465,960$ \\
LPG (ton) & 74 & 7 & 64 & 145 \\
Chemical (ton) & 17 & - & 11 & 28 \\
Coal (ton) & 9743 & 4781 & - & 14,524 \\
Wood (ton) & 507 & 1328 & 759 & 2594 \\
Natural gas (Sm ${ }^{3}$ ) & - & - & 335,095 & 335,095 \\
Rice husk & - & - & 688 & 688 \\
(briquettes) & - & - & 3765 & 3765 \\
Steam (ton) & 34,254 & 21,033 & 36,423 & 91,710 \\
CO 2eq (ton) & 7103 & 4856 & 5986 & 17,945 \\
PCDD/F ( $\mu$ g) & 3224 & 35,200 & 131,444 & 169,868 \\
COD (kg) & 1111 & 7854 & 2272 & 11,237 \\
Solid waste (ton) & 36,241 & 278,188 & $1,043,259$ & $1,357,688$ \\
Waste water (m ${ }^{3}$ ) & - & &
\end{tabular}

Note: This summary includes the RECP benefits of all companies that participated in the project throughout its entire duration.

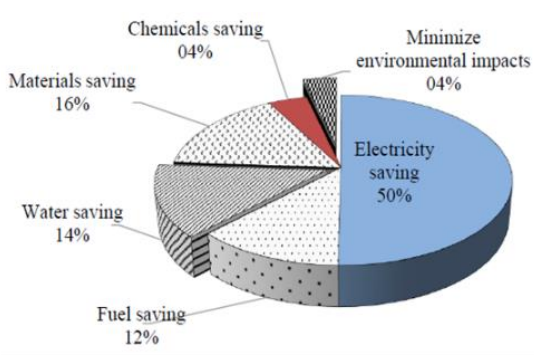

Ninh Binh Province

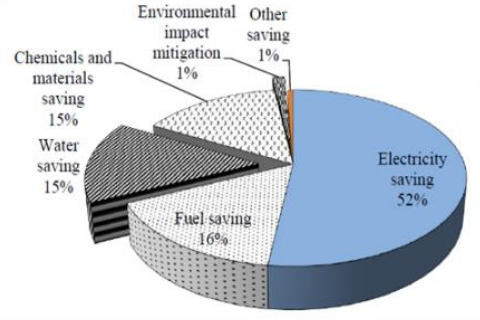

Da Nang Province

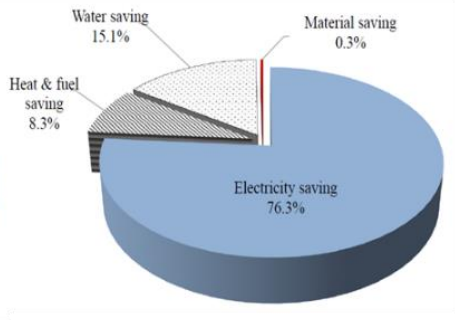

Can Tho Province

Figure 4. Classification of resource efficient and cleaner production (RECP) options [41].

Illustrative Examples of Results

Tables 2 and 3 highlight illustrative examples of RECP options identified and implemented by two companies with the support of the Project. In these companies, more basic good housekeeping interventions were coupled with technology and equipment investments. The pay-back time of the investments is therefore higher than the average, though the environmental and economic benefits are significant in absolute numbers.

The Project worked with these companies toward the establishment of an RECP team, i.e., a team of employees responsible for suggesting and implementing RECP options. Such teams have proved highly successful and will contribute to mainstreaming a "resource efficiency culture" across the company departments, ensuring that the options implemented are well managed and potentially replicated or scaled up in the future. 
Table 2. RECP assessments with companies—company case study 1.

\begin{tabular}{|c|c|c|c|}
\hline $\begin{array}{l}\text { Industry } \\
\text { Sector/Product }\end{array}$ & \multicolumn{3}{|c|}{ Paper Factory } \\
\hline \multirow[b]{2}{*}{ Production process } & \multicolumn{3}{|c|}{$\begin{array}{l}\text { The paper factory produces kraft, industrial roll, and carton package with the capacity of } 15,000 \text { tons/year. The company has joined Project since January } 2016 \text { and has } \\
\text { established a RECP team with nine members. The paper production process involves the following steps: }\end{array}$} \\
\hline & $\begin{array}{l}\text { (a) Scrap paper } \\
\text { (b) Material classification and preparation } \\
\text { (c) Pulp production } \\
\text { (d) Pulp preparation before wire } \\
\text { (e) Wire pulp into roll } \\
\text { (f) Product finalization and storage }\end{array}$ & \multicolumn{2}{|c|}{$\begin{array}{l}\text { Scrap paper } \\
\text { Material classification and preparation } \\
\text { Pulp production } \\
\text { Pulp preparation before wire } \\
\text { Wire pulp into roll } \\
\text { Product finalization and storage }\end{array}$} \\
\hline \multirow{24}{*}{$\begin{array}{l}\text { RECP options } \\
\text { implemented }\end{array}$} & \multicolumn{3}{|c|}{22 RECP options have been implemented between January 2016 and January 2019, while 4 have not been implemented yet. } \\
\hline & \multicolumn{2}{|c|}{ No. $\quad$ Implemented RECP options } & Benefits \\
\hline & 1 & Issue regulation for cleaning and maintenance of electrical cabinets and motors & $\begin{array}{l}\text { Engine runs more durable; and reduced } \\
\text { power consumption }\end{array}$ \\
\hline & 2 & $\begin{array}{l}\text { Install electricity meter for every production line to control separately the electricity consumption } \\
\text { benchmark for production lines }\end{array}$ & Monitoring norms used to detect leaks and losses. \\
\hline & 3 & Repair roof to increase natural light and ventilation to save electricity & Reduced power consumption \\
\hline & 4 & Invest the solar battery system & $\begin{array}{l}\text { Increase of renewable energy use and reduced } \\
\text { power consumption }\end{array}$ \\
\hline & \multirow{2}{*}{$\begin{array}{l}5 \\
6\end{array}$} & \multirow{3}{*}{$\begin{array}{l}\text { Control and regulate water consumption for washing conveyor } \\
\text { Increase treatment efficiency of WWT system to raise recycling water rate } \\
\text { Investment in four new high-pressure sprayers (two big machines and two small machines) for } \\
\text { washing conveyor }\end{array}$} & Reduced water consumption \\
\hline & & & Reduced pollutants in waste water \\
\hline & 7 & & Reduced water consumption \\
\hline & 8 & $\begin{array}{l}\text { Build roof for material storing area or press material for better maintenance and control } \\
\text { consumption benchmark }\end{array}$ & Reduced materials consumption \\
\hline & 9 & \multirow{3}{*}{$\begin{array}{l}\text { Remind worker to collect pulp on floor and clean floor at the end of working shift } \\
\text { Regular monitoring of the quality of the pulp, especially the concentration of pulp (homogeneity of pulp) } \\
\text { before making paper. }\end{array}$} & Reduced materials consumption \\
\hline & 10 & & $\begin{array}{l}\text { Increasing quality of paper, reduced } \\
\text { materials consumption }\end{array}$ \\
\hline & 11 & & Reduced fuel consumption \\
\hline & \multirow{2}{*}{$\begin{array}{l}12 \\
13\end{array}$} & $\begin{array}{l}\text { Insulate steam distribution pipeline of lines } 4 \text { and } 2 \\
\text { Insulate condensate recovering pipeline and a number of steam containing tanks of lines } 1,2,4,6 \\
\text { Insulate condensate recovering tanks }\end{array}$ & Reduced fuel consumption \\
\hline & & \multirow{2}{*}{$\begin{array}{l}\text { Insulate condensate recovering tanks } \\
\text { Invest supply water treatment system for boiler }\end{array}$} & Reduced fuel consumption \\
\hline & \multirow{2}{*}{14} & & Extended boiler life \\
\hline & & \multirow{2}{*}{$\begin{array}{l}\text { Training to improve skill and responsibility of boiler operation workers } \\
\text { Use good quality wood (with humidity less than } 40 \% \text {, wood dried to meet less than } 35 \% \text { humidity } \\
\text { before using }\end{array}$} & Reduced fuel consumption \\
\hline & 16 & & Improved quality and reduced operating cost \\
\hline & 17 & Remove scale and blowdown regularly & Improved quality and reduced operating cost \\
\hline & 18 & Replace three existing blowers by one of $7.5 \mathrm{HP}$ for supplying wind into boiler & Reduced electricity consumption \\
\hline & 19 & Adjust frequency of smoke fan based on suction pressure to ensure balance between fire and wind & Reduced electricity consumption \\
\hline & 20 & Install meter to measure steam consumption for each line & Reduced electricity consumption \\
\hline & 21 & Increase water removing capacity by investing in long net paper making machine & Reduced water consumption \\
\hline & 22 & Invest in fluidized boiler system, capacity of 8 tons $/ \mathrm{h}$ with three stages steam system. & Reduced fuel consumption and operating cost \\
\hline
\end{tabular}


Table 2. Cont.

\begin{tabular}{|c|c|c|}
\hline $\begin{array}{l}\text { Industry } \\
\text { Sector/Product }\end{array}$ & Paper Factory & \\
\hline \multirow{15}{*}{ Benefits } & Resource benefits: & \\
\hline & Materials savings—scrap paper (tons/year) & 213 \\
\hline & Water savings $\left(\mathrm{m}^{3} /\right.$ year $)$ & 6592 \\
\hline & Electricity savings (MWh/year) & 2460 \\
\hline & Fuel savings (tons of coal/year) & 1110 \\
\hline & Environmental benefits (reduced emissions): & \\
\hline & Reduction of solid waste (tons/year) & 15 \\
\hline & Reduction of wastewater ( $\mathrm{m}^{3} /$ year $)$ & 5274 \\
\hline & Reduction of $\mathrm{CO}_{2}$ (tons/year) & 2260 \\
\hline & Reduction of Teq PCDD/F ( $\mu \mathrm{g} /$ year) & 1013 \\
\hline & Avoided COD emission (kg/year) & 922 \\
\hline & Financials: & \\
\hline & $\begin{array}{l}\text { Total of investment cost for RECP (billion VND) } \\
\end{array}$ & 15.7 \\
\hline & Total of saving cost (billion VND/year) & 5.8 \\
\hline & Pay-back time & Less than 3 years \\
\hline
\end{tabular}


Table 3. RECP assessments with companies—company case study 2.

\begin{tabular}{|c|c|c|c|}
\hline Industry Sector/Product. & \multicolumn{3}{|c|}{ Floating Glass } \\
\hline \multirow[b]{2}{*}{ Production process } & \multicolumn{3}{|c|}{$\begin{array}{l}\text { The company produces } 300 \text { tons of construction white glass per day. The number of employees in the factory are } 300 \text {. The company joined the } \\
\text { Project since January 2016. The company's RECP team has four members. The float glass production process involves the following steps: }\end{array}$} \\
\hline & $\begin{array}{l}\text { (a) } \\
\text { (b) } \\
\text { (c) } \\
\text { (d) } \\
\text { (e) } \\
\text { (f) }\end{array}$ & $\begin{array}{l}\text { Raw materials } \\
\text { Weighing, sieving, mixing } \\
\text { Melting }\left(1600^{\circ} \mathrm{C}\right) \\
\text { Rolling and cooling } \\
\text { Cutting, quality control } \\
\text { Final product }\end{array}$ & \\
\hline \multirow{28}{*}{ RECP options implemented } & \multicolumn{3}{|c|}{ The following 11 RECP options have been implemented under the Project since January 2016.} \\
\hline & No. & Implemented RECP options & Benefits \\
\hline & 1 & Fix the bad contact and invest in an infrared thermometer to monitor temperature & Reduced electricity consumption \\
\hline & 2 & Replace these lamps by compact $75 \mathrm{~W}$ or $50 \mathrm{~W}$ when they are damaged & Reduced electricity consumption \\
\hline & 3 & Transfer some capacitors from central to branch power load to reduce the motor voltage drop & Reduced electricity consumption \\
\hline & 4 & Contact local electric authority to decrease wire voltage to $380 \pm 2.5 \%$ & Reduced electricity consumption \\
\hline & 5 & $\begin{array}{l}\text { Put more attention in managing and controlling the status of material and a clear plan of } \\
\text { buying/storage }\end{array}$ & Reduced materials consumption \\
\hline & 6 & Heat up fuel (coal) to optimal temperature before being sprayed into burning chamber & Reduced fuel consumption \\
\hline & 7 & Have a plan for furnace maintenance to repair partially broken area & Reduced fuel consumption \\
\hline & 8 & To change to more efficient heater for melting tin tank & Reduced electricity consumption \\
\hline & 9 & Maintain and replace by the new furnace & Reduced electricity consumption \\
\hline & 10 & Should be equipped with a roof to protect materials and control their consumption & Reduced materials consumption \\
\hline & 11 & Take advantage of heat in the emission to dry fuel & Reduced fuel consumption \\
\hline & \multicolumn{3}{|c|}{ Resource benefits: } \\
\hline & \multicolumn{3}{|c|}{ Chemicals savings } \\
\hline & & - Sand (tons/year) & 124 \\
\hline & & - Soda (tons/year) & 32 \\
\hline & & Electricity savings (MWh/year) & 3700 \\
\hline & & Fuel savings (tons of coal/year) & 3431 \\
\hline & \multicolumn{3}{|c|}{ Environmental benefits (reduced emissions): } \\
\hline & & Reduction of solid waste (tons/year) & 343 \\
\hline & & Reduction of wastewater ( $\mathrm{m}^{3} /$ year) & 12,715 \\
\hline & & Reduction of $\mathrm{CO}_{2}$ (tons/year) & 12,465 \\
\hline & & Reduction of Teq PCDD/F ( $\mu \mathrm{g} /$ year) & 2512 \\
\hline & \multicolumn{3}{|c|}{ Financials: } \\
\hline & & Total of investment cost for RECP (billion VND) & 103 \\
\hline & & Total of saving cost (billion VND/year) & 18.5 \\
\hline & & Pay-back time & Around 5 years \\
\hline
\end{tabular}




\subsection{Results-Park Level Interventions}

The Project's activities entailed the identification of industrial symbiosis opportunities through the analysis of the inputs/outputs of the companies, bilateral discussions with park management, and companies, opportunity identification workshops, and a review of international experiences. Together with the park management and the tenant companies, the project team prioritized the identified industrial symbiosis opportunities qualitatively based on their likely achievability, anticipated benefits (economic, environmental, and social), and the interest from relevant stakeholders (e.g., park management, relevant companies). The team conducted feasibility studies for prioritized opportunities. These covered technical feasibility (e.g., technology options, required capacities), assessment of environmental and social benefits, economic feasibility (e.g., CAPEX, OPEX, return on investment), and a review of possible implementation options. The results of the feasibility studies were presented and discussed with the park management and relevant companies, and customized support was provided by the project team to assist in their implementation.

Training was provided and workshops were organized for more than 130 participants in the industrial parks targeted by the Project to present and discuss the results of the feasibility analyses. This was also an opportunity used to build synergistic connection between the respective stakeholders of each IS opportunity and understand better the bottlenecks, and technological requirements and expertise needs to implement them. Further capacity building was provided to help with the implementation.

In addition to the industrial symbiosis activities, the Project entailed other park level interventions, including (a) assessments of the central wastewater treatment plants in the pilot parks in order to support their performance improvement; (b) development of park management assessment tool and strategy to better engage the park management; (c) compilation of good practice examples of centralized services existing in 15 industrial parks and review of shared park level services that need to be strengthened in Viet Nam; and (d) development of a solid waste inventory to identify and assess opportunities of waste recycling and reuse.

Table 4 summarizes the results of the Project on the identification and development of industrial symbiosis opportunities in the pilot parks (Khanh Phu IZ, Hoa Khanh IZ, and Tra Noc 1\&2 IZ).

By the end of the Project, for a total of 18 opportunities and corresponding feasibility studies, two opportunities are already implemented, five are under implementation, and five opportunities are planned. This means two-thirds of the opportunities detected have been adopted by stakeholders who are committed to their implementation. If all opportunities are implemented, $70.5 \mathrm{KtCO} /$ year, $885,333 \mathrm{~m}^{3}$ of freshwater, and $84,444 \mathrm{t}$ of waste are expected to be saved every year. The payback time for these opportunities is expected to range between 3 months and 8 years.

Table 4. Results from industrial symbiosis work in pilot industrial parks (June 2019).

\begin{tabular}{|c|c|c|c|c|}
\hline Item & $\begin{array}{l}\text { Khanh Phu IZ } \\
\text { (Ninh Binh) }\end{array}$ & $\begin{array}{l}\text { Hoa Khanh } \\
\text { IZ (Da Nang) }\end{array}$ & $\begin{array}{l}\text { Tra Noc } 1 \& 2 \\
\text { IZ (Can Tho) }\end{array}$ & Total \\
\hline Number of companies surveyed & 22 & 57 & 58 & 137 \\
\hline \multicolumn{5}{|c|}{ Number of industrial symbiosis opportunities } \\
\hline Identified & 14 & 22 & 25 & 61 \\
\hline Feasibility studies & 4 & 7 & 8 & 19 \\
\hline Feasible and up for implementation & 0 & 4 & 6 & 10 \\
\hline Already implemented & 0 & 1 & 1 & 2 \\
\hline \multicolumn{5}{|c|}{ Total environmental benefits for feasible opportunities } \\
\hline GHG (tCO2/yr) & 24,955 & 18,190 & 27,331 & 70,475 \\
\hline Water $\left(\mathrm{m}^{3} / \mathrm{yr}\right)$ & 0 & 885,333 & 0 & 885,333 \\
\hline Waste $(\mathrm{t} / \mathrm{yr})$ & 82,440 & 2004 & 0 & 84,444 \\
\hline \multicolumn{5}{|c|}{ Total economic benefits for feasible opportunities } \\
\hline Average payback period (min-max) & $0.3-7.5$ year & $0.3-7.9$ year & $1-3$ year & \\
\hline Capital investment (USD) & $1,834,741$ & 999,385 & $1,745,113$ & $4,579,239$ \\
\hline Capital already invested or committed (USD) & 0 & 999,385 & $1,745,113$ & $2,744,498$ \\
\hline Savings (USD/yr) & $2,186,625$ & 466,134 & 790,655 & $3,443,414$ \\
\hline
\end{tabular}


Illustrative Examples of Results

A map with industrial symbiosis opportunities selected for feasibility studies in Tra Noc 1\&2 IZ is presented in Figure 5. Similar maps have been produced for the two other parks. The figure shows that a diverse set of opportunities are being considered for further development and implementation involving different company types as well as the management board of the park. The opportunities cover exchanges of wastes and by-products (e.g., biomass, waste steel, waste paper/cardboard), energy (e.g., shared biomass boiler to produce steam for multiple tenant companies), water (e.g., water storage tank at the centralized wastewater treatment plant to facilitate the reuse of industrial wastewater among companies), and shared services (e.g., coordination of joint company activities in the park by the IZ management board, collection and transport of wastes, training). Industrial symbiosis can interlink traditionally separate companies in a collective approach to create competitive advantages involving physical exchange of materials, energy, water, and/or by-products, as per the definition of Chertow [36].

Tables 5 and 6 highlight illustrative examples of industrial symbiosis opportunities implemented or under implementation with the support of the Project. The examples include a high investment opportunity with significant fossil fuel savings benefits and a payback time of 3 years and a lower investment opportunity with diversified benefits and a payback time of just 3 months. 


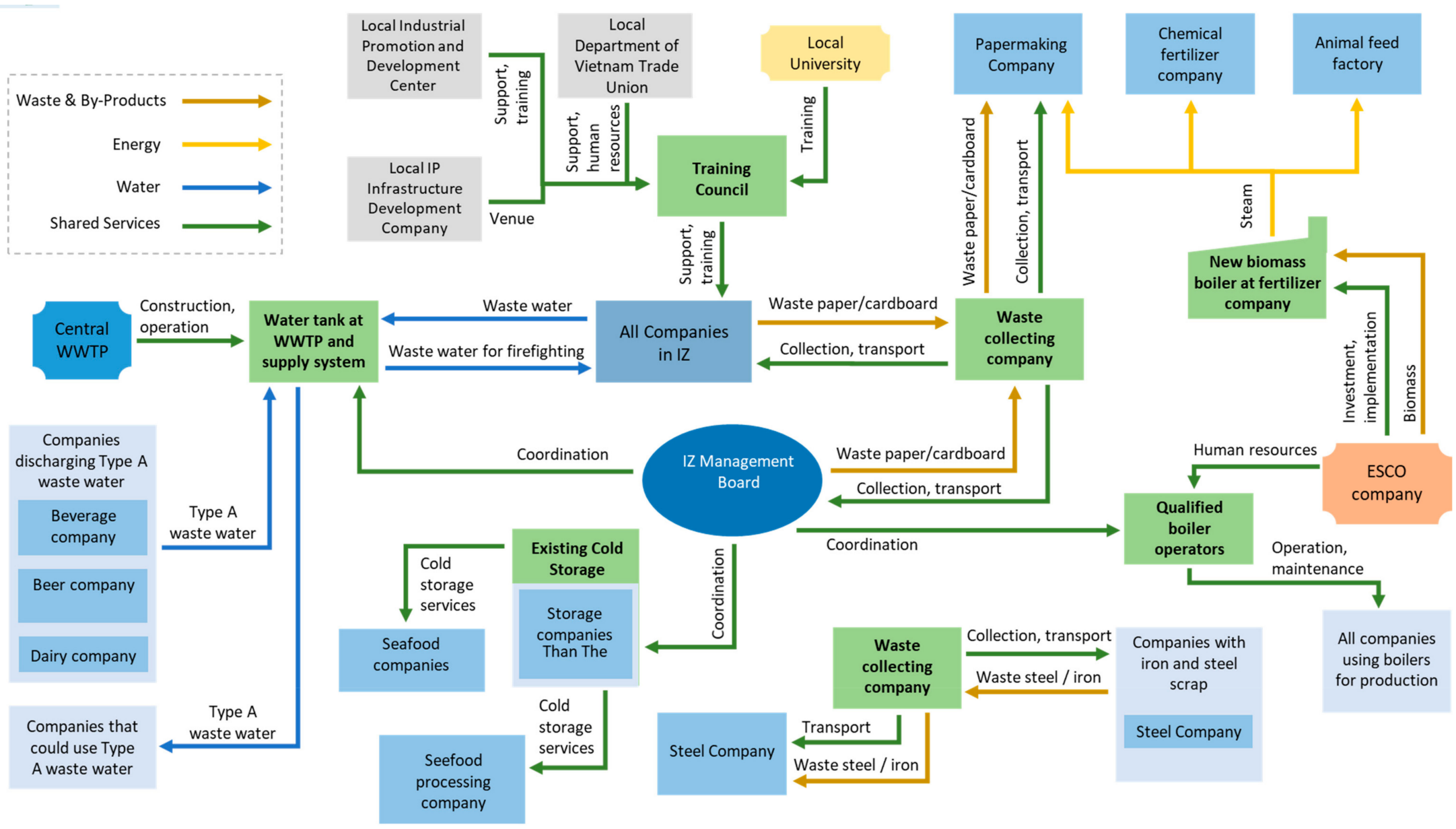

Figure 5. Industrial symbiosis opportunities selected for feasibility studies in Tra Noc IZ (Can Tho Province) [42]. 
Table 5. Development of industrial symbiosis opportunities—case study 1 [42].

\begin{tabular}{cl}
\hline IS Opportunity & Biogas Recovery at One Company for Use As Fuel in the Boiler of an Adjacent Company. \\
\hline Key challenges & B $\begin{array}{l}\text { Bogas production needs to meet the minimum amount required for the boiler to operate. } \\
\text { Connecting with the existing system, having an automated control system, and all the additional equipment needs to meet the } \\
\text { standard of the boiler. }\end{array}$ \\
\hline Solutions & - The biogas supplier should engage with the partner company to ensure the stability of the biogas produced. \\
\hline Stakeholders involved & Management of the two companies. \\
\hline Status of implementation & Implemented. \\
\hline Environmental savings & - Reduction in biomass consumption by $\sim 33 \%$. \\
\hline & Reduction in emissions by about $17,044 \mathrm{t}$ CO2eq/year. \\
\hline
\end{tabular}

- Improved work environment and health conditions for workers because of reduced emissions.

Social benefits

- Awareness building on environmental, resource efficiency, and monetary measures to be gained by installation of the new system.

- Training of workers on the management of the new installed system.

- Improved environmental and health conditions in neighboring communities.

Financial aspect

\begin{tabular}{cl} 
Savings (USD/yr) & 5.39 billion VND VND/year in biomass costs reduction (231,420 USD/year). \\
\hline Required investment & 2.6 billion VND (112,294 USD). \\
\hline Payback time & 3 months. \\
\hline & $\begin{array}{l}\text { The investment was done by the energy company.Additional financing was provided by } \\
\text { state incentives as described in Decree } 04 / 2009 / \mathrm{ND}-\mathrm{CP}(14 / 01 / 2009):\end{array}$
\end{tabular}

- A rebate of $50 \%$ of land use fees, land renting, and could be paid in instalments with a maximum timeframe of five years;

Financing options

- Support of $50 \%$ building investment capital-including $40 \%$ from the state budget, $10 \%$ from the local budget;

- Support of $50 \%$ of the transportation cost of the waste from the emission source to the treatment facility and $50 \%$ of the electricity cost for direct production;

- Depreciation of fixed assets: depreciated two times faster than the current regulation. 
Table 6. Development of industrial symbiosis opportunities—case study 2 [42].

\begin{tabular}{|c|c|c|}
\hline IS Opportunity. & \multicolumn{2}{|c|}{ Mutualization of the Use of Boilers between Three Companies. } \\
\hline Key challenges & \multicolumn{2}{|c|}{$\begin{array}{l}\text { - The quality of the steam has to meet the technical standard. } \\
\text { - The steam demand and capacity is dependent on production, and that implies that it fluctuates. } \\
\text { The changing nature of production demand implies change in steam requirements of the companies implementing } \\
\text { the symbiosis. } \\
\text { - Manpower for operation and maintenance of the system. } \\
\text { - Firefighting system requirements. }\end{array}$} \\
\hline Solutions & \multicolumn{2}{|c|}{$\begin{array}{l}\text { - Negotiate commitments between an ESCO and the companies that have a demand. } \\
\text { - The ESCO company has to take charge of maintenance costs for the redundant boiler. } \\
\text { Ensure that the capacity of the boiler is sufficient to cater to the requirements when the steam demand increases for any } \\
\text { of the companies. }\end{array}$} \\
\hline Stakeholders involved & \multicolumn{2}{|c|}{ Management of the three companies involved. } \\
\hline Status of implementation & \multicolumn{2}{|l|}{ Under implementation. } \\
\hline Environmental savings & \multicolumn{2}{|c|}{$\begin{array}{l}\text { - } \quad \text { Reduction in coal consumption (about } 10,000 \text { tons/year), replaced by } 29,000 \text { tons per year. } \\
\text { - } \quad \text { Reduction in emissions equivalent to } 26,427 \text { tons CO2e/year and } 6408 \mu \mathrm{g} / \text { year PCDD/F. } \\
\text { - Slight reduction in emission from transportation because of the mutualization of the fuel supply. }\end{array}$} \\
\hline Social benefits & \multicolumn{2}{|c|}{$\begin{array}{l}\text { - } \quad \text { Reduction in the risk of environmental incidents. } \\
\text { - } \quad \text { For ESCO company: } 6 \text { job created for boiler operation; and } 11 \text { job saved for current boiler operators. } \\
\text { - } \quad \text { Training of workers on the management and operations of the new fluidized bed boiler technology } \\
\text { Reduction in the risk of environmental accidents. }\end{array}$} \\
\hline \multirow{4}{*}{ Financial aspects } & \multicolumn{2}{|r|}{25.2 billion VND (1,082,846 USD). } \\
\hline & Required investment & $\begin{array}{l}22.5 \text { billion VND (966,113 USD) with OPEX of } 17,742.3 \text { million VND }(762,388 \\
\text { USD). }\end{array}$ \\
\hline & Payback time & 3 years. \\
\hline & Financing options & $\begin{array}{l}\text { Bank loan }(60 \% \text { of the total amount). As mentioned in Decree } 82 \text {, the company } \\
\text { could apply for a loan from the Vietnam Development Bank. The specific bank } \\
\text { will be selected by the company. }\end{array}$ \\
\hline
\end{tabular}




\subsection{Summary of Project Results}

The results of the Project's interventions in the pilot industrial parks can be summarized as follows [41]:

- Intensive capacity-building and awareness-raising at all levels. A total of 264 local officials (from the Provincial People's Committee, Department of Science and Technology, Department of Natural Resources, Department of Industry and Trade, industrial park management of three provinces) and government officials, experts, researchers (from the Ministry of Natural Resources and Environment (MONRE), Ministry of Science and Technology (MOST), Ministry of Industry and Trade (MOIT), MPI, Ministry of Construction (MOC), Ministry of Finance (MOF), Department of Natural Resources, Department of Industry and Trade, Department of Commerce, Viet Nam Union of Science and Technology Associations, Environmental Industry Association, Vietnam Small and Medium Enterprise Association and universities) were trained on international EIP models, the social and environmental requirements of EIP development, the development, implementation and management of EIP, and new policy and technical guidelines for EIP in Viet Nam. A total of 43 local and national-level officials took part in study tours in Japan, China, Denmark, Austria, and Switzerland and were trained in the establishment, development, and operation of EIPs, their institutional and policy requirements, technical and social minimum requirements, and industrial symbiosis.

- The ratio of RECP options identification and their implementation is around $80 \%$, which is considered to be high. RECP options related to electricity savings account for the highest proportion (over 50\%) of total options identified and implemented in the parks in all three provinces.

- The process of implementing RECP options helped companies achieve substantial benefits in terms of efficient use of resources (electricity, water, fuel, raw materials, chemicals), gaining economic benefits and reducing emissions to the environment as well as improving working conditions for workers. The RECP options implemented range from simple good housekeeping to more complex technology modifications, covering a range of industry sectors. They demonstrated value in improving the economic and environmental performance of companies in Viet Nam, in particular resource intensive industries such as food, cement, textiles, mechanical processing, and fertilizer production.

- Capacity-building in chemicals management in industrial parks and their companies. A total of 292 technical managers and staff from companies located in three industrial parks and central officials were trained on electricity efficiency in IZs and chemical management in industries.

- Capacities in resource efficiency and cleaner production (RECP) built/strengthened among company staff. Four hundred one company staff and technical managers from companies located in three selected industrial parks were trained through 8 classroom RECP trainings organized between January 2016 and September 2017.

- Implementation of resource efficiency measures in selected industrial processes. Seventy three companies in the three selected IZs assessed in RECP and in potential for implementation of clean and low-carbon technology. The total number of RECP solutions suggested for the 73 companies was 1039 , of which 933 were implemented.

- Identification of industrial symbiosis options in selected parks. A total of 61 opportunities were identified in the four IZs, of which 18 were selected for further development in a more detailed feasibility study.

- Increased public awareness on issues concerning EIP development. A total of 2163 participants from organizations (including scientific institutions (universities), non-governmental organizations (NGOs), public institutions, IZ authorities and associations) were identified and participated in awareness-raising events. 
- The results achieved at company level contributed to the development of eco-enterprises and EIPs, as defined in Government Decree No. 82/2018 on regulating the management of industrial and economic zones [14].

\section{Discussion and Conclusions}

The application of the policy, company and park level interventions as part of the Project "Implementation of eco-industrial park initiative for sustainable industrial zones in Viet Nam" demonstrated their value in contributing to the development and implementation of EIP practices in the country. Rather than stand-alone solutions, multi-disciplinary EIP concepts are most effective if applied as part of the integrated top-down approach (policy support as entry point for interventions) combined with a bottom-up approach (industrial park as entry point).

On policy development, a continuous and integrated effort over the four years of the Project to create awareness and build capacity on the EIP concept and its environmental, economic, and social benefits at all levels (e.g., policy maker, provincial authorities, tenant companies) was critical to the success of the policy interventions and successfully engaging all project stakeholders. A committed group of policy-makers with clear guidance from the highest political level was essential in ensuring buy-in from different ministries and for gaining clarity regarding the process to be followed in implementing the Decree and circulars, thereby setting the stage for future EIP development in the country. In the near future, the resulting complete set of environmental, economic, and social indicators will be considered by the Government of Viet Nam as a consolidated guideline to be adopted for the implementation of Decree 82. The national process toward the definition of clear policy and regulations for EIPs has been set by Decree 82, which provides a strong legal baseline for the implementation. The implementation offers a number of opportunities, but also faces constraints in Vietnamese legislation as concrete opportunities to develop industrial symbiosis are still limited by regulation. Scaling up EIPs will involve seeking inputs from different stakeholders, including the private sector, and will require the coordinated efforts of different ministries. To support the implementation of Decree 82, it is envisaged that ministerial circulars will be developed for both industries and government authorities to regulate the detailed technical aspects and thereby streamline the implementation and approval processes (e.g., for reuse of industrial effluent and by-products in a safe and sustainable manner).

On company interventions, a large proportion (45\%) of the total RECP options identified through the Project were examples of good housekeeping with low investment costs and were easy for the companies to implement. Some of the participating companies only implemented the simple RECP options with low investment costs, as these could often be easily added to the maintenance plan of the company. More complex technology options require higher company investments and, as a result, approval from the company's management board.

All companies implemented options for electricity saving as these were easier to implement. A large proportion of the water savings options were examples of good housekeeping, as well as process control to improve effectively the awareness of water use. Options for fuel savings were often a process modification to optimize the process of fuel use in terms of both planning and technology.

On park level interventions, it was clear that untapped opportunities exist for industrial symbiosis for energy, water, and material efficiency gains in industrial parks. The implementation of industrial symbiosis offers a lot of business opportunities which generate economic, environmental, and social benefits to the industrial park overall, park management, tenant companies, and local community. This is evidenced by the Project being able to identify over 61 industrial symbiosis opportunities for parks, for which a total of 18 feasibility studies have been undertaken. Industrial symbiosis also faces challenges in the Vietnamese legislation. For example, it is still cumbersome for an industrial park manager to obtain government approval to install renewable energy facilities in the park area or to be able to provide water services from treated wastewater to tenant companies [43]. There is currently no detailed guidance on how to obtain the approval from the government for reusing wastewater. It is a 
long process to obtain government approval for water reuse, because detailed data is required by the government on the water quality and intended reuse. Companies must discharge their effluent to a centralized wastewater treatment facility or other treatment unit (Article 9, circular 35/2015TT-BTNMT). Therefore, companies are not allowed to transfer their wastewater to another company which does not have a wastewater treatment function registered in its business license. Industrial water reuse is very sensitive, because authorities are concerned that companies will take advantages of the approval to discharge unqualified treated wastewater into the environment.

Efforts are underway to address these challenges. The Government of Viet Nam is pushing for the country to transition into a circular economy and various initiatives are under development and being implemented to facilitate this transition. The recently approved Decree 82/2018/ND-CP "Management of Industrial Parks and Economic Zones" prescribes the planning, establishment, and operation of policies on, and state management of, industrial parks and economic zones. The Decree explicitly mentions instructions for the implementation of EIPs. Value recovery and reuse of industrial by-products, energy, and water are key elements of the EIP concept. As part of Decree 82 it is compulsory for an industrial park to have at least one industrial symbiosis implemented in order to be recognized as an eco-industrial park. The Decree 82 aims to further remove regulatory barriers that could hamper EIP development, including the reuse of industrial water and industrial by-products/waste. To support the implementation of Decree 82, it is envisaged that ministerial circulars on industrial water reuse will be developed. These circulars will serve as national technical guidelines for both industries and government authorities to streamline the approval processes for the reuse of industrial water and by-products in a safe and sustainable manner.

\section{Lessons Learned and Next Steps}

Some insights and lessons learned from the work on policy development as well as company and park level EIP interventions are that:

- Although the new decree 82/2018/NĐ-CP increases the transparency of EIP development in the country, legal barriers to implement EIPs in reality still exist, and these mainly relates to lack of available and reliable data, guidelines on waste and wastewater reuse, and recycling and minimum standards to reuse it [30].

- Initial awareness raising and creating early successes in the Project is essential. Convincing companies that it is for their own benefit can take a lot of time and effort. Once the early adopters have results, then all the neighboring companies wish to join and benefit from the Project.

- Overall, there is often a lack of available data at company, park, provincial, and national level. Data on the quantities and qualities of resources (e.g., raw materials, wastes, and by-products, energy, and water) is needed before being able to assess the potential for industrial symbiosis in an industrial park. Collecting these basic data can be a time-consuming process. Therefore, strengthening resource monitoring at all levels should be a priority.

- Commitment of the company management board is the key factor to the success of the company level interventions. At companies with high commitment, many RECP options are implemented immediately with specific benefits, encouraging enterprises to implement and maintain options till the end of the RECP programme.

- The company teams established play an important role in implementing and maintaining the effectiveness of the RECP and industrial symbiosis options identified. The teams need to be supported by the management board of the companies as well as IZ management, and maintained after the actual assessments have been completed in order to ensure that feasible options are implemented effectively.

- Technical assistance provided to companies demonstrated that RECP options can be low- or no cost and easy to implement with high returns on companies' investments. Simple and no investment cost options should be implemented immediately. In addition to the immediate environmental 
and financial savings, this will also motivate and create confidence for the company to deploy RECP options with higher investment costs.

- For technology upgrades and investments, it is necessary to inform companies on available green financial funds and preferential loans to implement the RECP and industrial symbiosis options and provide support on how to access these funds. This was one of the key drivers for the Project to prepare a customized handbook on accessing green financing in Viet Nam [44].

The development of industrial symbiosis in industrial parks in Viet Nam is subject to similar success factors which apply internationally (e.g., [10,45,46]), including:

- Feasible distances: This is generally a key success factor as transportation can make up a significant proportion of the costs to enable an industrial synergy. A clear distinction must be made between synergies inside and outside an industrial park (e.g., material exported for road construction). Obviously, this latter case is more sensitive to transportation issues.

- Viable technology and equipment: Modification and investment in technologies are often required to implement industrial symbiosis. For instance, a by-product may need to be processed to meet the technical and market requirements. Without a suitable and proven technology available to treat, convert or transport a by-product, a synergy project would be not feasible.

- Diversity of industries: Having different industrial sectors usually results in a wide variety of resource input and output flows available for inter-industry exchanges. Similarly, having companies of different sizes (including SMEs) can facilitate the development of symbiosis by offering opportunities for valorizing different volume streams.

- License to operate: Policy and regulations can help improve resource efficiencies at company and industrial park levels (Moreau et al. 2017). As outlined above, regulations in Viet Nam are currently a barrier to the development of industrial symbiosis, because by-products and effluent are traditionally considered to be waste and are therefore constrained by stringent regulations to avoid illegal disposal of contaminated material.

- Recognize full set of benefits: The benefits of industrial symbiosis often go beyond return on-investment, as the benefits can also cover risk mitigation, improved productivity, and improved environmental and social performance. Investment decisions must therefore account for the full set of economic, environmental, and social benefits.

- Return on investment: The implementation of industrial symbiosis needs a favorable return on investment and so-called low-hanging fruit for the beneficiaries, as often the decision on their investment is competing with investments in other areas.

- Access to finance: Investments can sometimes be significant to implement industrial synergies. This is particularly the case for utility synergies and shared infrastructures in industrial parks. Financial incentives can help decreasing the payback period. As industrial symbiosis often require an investment, the availability of financing solutions is clearly a key factor for successful implementation [16].

Although EIP concepts have been disseminated across the three provinces of the projects and technical support provided, industrial parks are widespread in Viet Nam, so continued efforts are required to disseminate and further replicate the approaches and outcomes of the Project to all industrial parks.

To overcome the above mentioned legal barriers to implement EIPs, circulars on how to implement are of outmost importance for the practical and wider EIP implementation in Viet Nam. This includes the formal adoption of minimum EIP requirements for social, economic, and environmental aspects and the need to provide implementation guidelines to companies, EIP managers, local authorities, and agencies [30].

MPI has been tasked to act as the focal point to draft the relevant circulars for the implementation of the decree. Collaboration between ministries is necessary for the future of the development and approval of these circulars. 
The work undertaken as part of the Project (2014-2019) will continue through the country level interventions as part of the Global EIP Programme, funded by the Swiss Government through State Secretariat for Economic Affairs of Switzerland (SECO). Viet Nam is one of the countries participating in this programme, together with Colombia, Egypt, Peru and Ukraine. The country level interventions of the new programme will focus on mainstreaming EIP in policies and regulations and implementing EIP approaches in pilot industrial parks.

Author Contributions: Conceptualization, A.F.; Data curation, A.F.; Funding acquisition, A.F; Supervision, J.S.; Validation, T.D.D., V.Q.H., and V.T.M.H.; Writing—original draft, A.F. and D.v.B.; Writing—review and editing, J.S., T.T.P., and N.T.A.

Funding: The project "Implementation of eco-industrial park initiative for sustainable industrial zones in Viet $\mathrm{Nam}^{\prime \prime}$ is undertaken with the financial support of the Global Environment Facility (GEF), the State Secretariat for Economic Affairs of Switzerland (SECO), and the United Nations Development Programme (UNDP). The main project partners are the Ministry of Planning and Investment (MPI) of Viet Nam, as well as relevant ministries and provincial authorities of Can Tho, Da Nang, and Ninh Binh.

Acknowledgments: UNIDO would like to express its gratitude to the institutions and professionals that contributed to the project, including the national and international experts who supported the development and implementation of specific assignments (e.g., Viet Nam National Cleaner Production Centre, Sofies Group, Sen26 Trading Consultant Company Limited, Viet Nam Academy of Social Sciences, Center for Environment and Community Development). The views expressed in this document are those of the authors and do not necessarily reflect the views of UNIDO and its governing bodies, nor those of the Government of Switzerland.

Conflicts of Interest: The authors declare no conflict of interest.

\section{References}

1. Côté, R.; Cohen-Rosenthal, E. Designing eco-industrial parks: A synthesis of some experience. J. Clean. Prod. 1998, 6, 181-188. [CrossRef]

2. Erkman, S.; Ramaswamy, R. Cleaner production at the system level: Industrial ecology as a tool for development planning. Clean. Prod. 2000, 2, 173-178.

3. Geng, Y.; Zhang, P.; Côté, R.P.; Fujita, T. Assessment of the national eco-industrial park standard for promoting industrial symbiosis in China. J. Ind. Ecol. 2009, 13, 15-26. [CrossRef]

4. GIZ. Guidelines for Sustainable Industrial Areas—Version 1.0 (October); Deutsche Gesellschaft für Internationale Zusammenarbeit (GIZ) GmbH: Eschborn, Germany, 2015.

5. Indigo Development. An Eco-industrial Park Definition for the Circular Economy. 2005. Available online: http://www.indigodev.com/Defining_EIP.html (accessed on 30 June 2017).

6. Lowe, E.A. Eco-Industrial Parks: A Handbook; Asian Development Bank: Manila, Philippines, 2001.

7. Massard, G.; Jacquat, O.; Zürcher, D. International Survey on Eco-Innovation Parks: Learning from Experiences on the Spatial Dimension of Eco-Innovation; FOEN: Bern, Switzerland, 2014.

8. UNIDO. Global Assessment of Eco-Industrial Parks in Developing and Emerging Countries: Achievements, Good Practices and Lessons Learned from Thirty-Three Industrial Parks in Twelve Selected Emerging and Developing Countries; United Nations Industrial Development Organization: Vienna, Austria, 2016.

9. WBG. Low-Carbon Zones-A Practitioner's Handbook; World Bank Group, Investment Climate Department: Washington, DC, USA, 2014.

10. UNIDO. Implementation Handbook for Eco-Industrial Parks; United Nations Industrial Development Organization: Vienna, Austria, 2017.

11. UNIDO; WBG; GIZ. An International Framework for Eco-Industrial Parks; World Bank Group: Washington, DC, USA, 2017.

12. GIZ. Sustainable Industrial Area Toolbox; Deutsche Gesellschaft für Internationale Zusammenarbeit (GIZ) GmbH: Eschborn, Germany, 2017.

13. Roberts, B.H. The application of industrial ecology principles and planning guidelines for the development of eco-industrial parks: An Australian case study. Appl. Ind. Ecol. 2004, 12, 997-1010. [CrossRef]

14. Government of Viet Nam Decree No.82/2018/ND-CP. Management of Industrial Parks and Economic Zones; Government of Viet Nam Decree No.82/2018/ND-CP: Hanoi, Vietnam, 2018.

15. Van Berkel, R. Regional Resource Synergies for Sustainable Development in Heavy Industrial Areas: An Overview of Opportunities and Experiences; Curtin University of Technology: Perth, Australia, 2006. 
16. WBG. Mainstreaming Eco-Industrial Parks; World Bank Group: Washington, DC, USA, 2016.

17. Veiga, L.B.E.; Magrini, A. Eco-industrial park development in Rio de Janeiro, Brazil: A tool for sustainable development. J. Clean. Prod. 2009, 17, 653-661. [CrossRef]

18. Yu, C.; de Jong, M.; Dijkema, G.P.J. Process analysis of eco-industrial park development. The case of Tianjin, China. J. Clean. Prod. 2014, 64, 464-477. [CrossRef]

19. Van Berkel, R.; Fujita, T.; Hashimoto, S.; Fujii, M. Quantitative Assessment of Urban and Industrial Symbiosis in Kawasaki, Japan. Environ. Sci. Technol. 2009, 43, 1271-1281. [CrossRef] [PubMed]

20. Van Beers, D.; Corder, G.; Bossilkov, A.; van Berkel, R. Industrial symbiosis in the Australian minerals industry-The cases of Kwinana and Gladstone. J. Ind. Ecol. 2007, 11, 55-72. [CrossRef]

21. MONRE. Report on National Environment: Viet Nam Industrial Environment; Ministry of Natural Resources and Environment of Viet Nam: Cầu Giấy, Vietnam, 2009.

22. UNIDO. Mpi Project Document 'Implementation of Eco-Industrial Park Initiative for Sustainable Industrial Zones in Viet Nam'; United Nations Industrial Development Organization: Vienna, Austria, 2014.

23. Government of Viet Nam. National Target Program of Use of Energy Saving and Efficiency for 2006-2015 Period; Prime Minister Decision 79/2006/QD-TTg: Hanoi, Viet Nam, 2006.

24. Government of Viet Nam. National Strategy of Integrated Solid Waste Management; Prime Minister Decision 2149/QD-TTg: Hanoi, Viet Nam, 2009.

25. Government of Viet Nam. Strategy of Resource Efficiency and Cleaner Production in Industry by 2020; Prime Minister Decision 1419/2009/QD-TTg: Hanoi, Viet Nam, 2009.

26. UNIDO. Eco-Industrial Parks Vietnam: Stakeholder Analysis and Development Roadmap; United Nations Industrial Development Organization: Vienna, Austria, 2019.

27. MPI. Annual Report 2018; Department of Economic Zone Management, Ministry of Planning and Investment: Hanoi, Viet Nam, 2018.

28. MPI. Annual Report 2017; Department of Economic Zone Management, Ministry of Planning and Investment: Hanoi, Viet Nam, 2017.

29. Chuc, N.G.; Dong, T.D.; Thuc, N.T. Efforts toward sustainable manufacturing: Cleaner production and eco-industrial parks in Viet Nam. In Environmental Sustainability in Asia: Progress, Challenges and Opportunities in the Implementation of the Sustainable Development Goals; Series 1-Viet Nam; Korea Environment Institute: Sejong, Korea, 2017.

30. UNIDO. Vietnam heads towards Eco-Industrial Parks. In Proceedings of the Second Expert Group Meeting: Implementation of Eco-Industrial Parks in Viet Nam: Opportunities, Challenges and Barriers, Ho Chi Minh City, Viet Nam, 8-9 November 2018; United Nations Industrial Development Organization: Vienna, Austria, 2018.

31. UNIDO. Eco-Industrial Parks Viet Nam: Social and Economic Indicators for Eco-Industrial Parks in Viet Nam; United Nations Industrial Development Organization: Vienna, Austria, 2019.

32. IFC. Technical and Financial Diagnostic of Eco-Opportunities in Industrial Parks of Viet Nam: Development of Eco-Industrial Park Technical Guidelines for Viet Nam; International Finance Corporation, World Bank Group: Washington, DC, USA, 2018.

33. Massard, G.; Leuenberger, H.; Dong, T.D. Standards requirements and a roadmap for developing eco-industrial parks in Viet Nam. J. Clean. Prod. 2018, 188, 80-91. [CrossRef]

34. UNIDO Resource Efficient and Cleaner Production (RECP). Available online: https://www.unido.org/cp/ o5153.html (accessed on 30 June 2017).

35. UNIDO. Cleaner Production Toolkit; UNIDO: Vienna, Austria, 2008.

36. Chertow, M.R. Industrial symbiosis: Literature and taxonomy. Annu. Rev. Energy Environ. 2000, $25,313-337$. [CrossRef]

37. IFC; MPI. National Technical Guidelines for Eco-Industrial Parks in Viet Nam; Ministry of Planning and Investment: Hanoi, Viet Nam, 2019; Unpublished.

38. UNIDO; MPI. Eco-Industrial Park Viet Nam Socio-Economic Requirements: A Review of International and Vietnamese Experiences; United Nations Industrial Development Organization: Vienna, Austria; Ministry of Planning and Investment of Viet Nam: Hanoi, Viet Nam, 2019.

39. UNIDO. Eco-Industrial Parks Viet Nam: Handbook on Prevention, Preparedness and Response to Environmental Accidents from Industrial Zones; United Nations Industrial Development Organization: Vienna, Austria, 2019. 
40. UNIDO. Eco-Industrial Parks Viet Nam: Vietnamese Policy Documents for Supporting Communities to Monitor Environmental Impacts from Industrial Zones; United Nations Industrial Development Organization: Vienna, Austria, 2019.

41. VNCPC; ENTEC. Provision of Services for RECP Training and Monitoring_Final Report; Viet Nam National Cleaner Production Centre and Environmental Technology Centre for United Nations Industrial Development Organization: Vienna, Austria, 2019.

42. VNCPC; Sofies. Reports on Industrial Symbiosis Feasibility Studies at Tra Noc Industrial Zone (Can Tho), Khanh Phu Industrial Zone (Ninh Binh), and Hoa Khanh Industrial Zone (Da Nang); Viet Nam National Cleaner Production Centre and Sofies Group for United Nations Industrial Development Organization: Vienna, Austria, 2019.

43. UNIDO; MPI. Review and Assess the Existing Legal Framework, Policies and Regulations on Industrial Parks in Viet Nam; United Nations Industrial Development Organization: Vienna, Austria, 2016.

44. UNIDO. Handbook on How to Access Green Financing in Viet Nam; United Nations Industrial Development Organization: Vienna, Austria, 2019.

45. Van Beers, D. Application of the Cleaner Production Framework to the Development of Regional Synergies in Heavy Industrial Areas: A Case Study of Kwinana (Western Australia); Curtin University of Technology: Perth, Australia, 2009.

46. Chiu, A.S.F.; Yong, G. On the industrial ecology potential in Asian Developing Countries. Appl. Ind. Ecol. 2004, 12, 1037-1045. [CrossRef]

(C) 2019 by the authors. Licensee MDPI, Basel, Switzerland. This article is an open access article distributed under the terms and conditions of the Creative Commons Attribution (CC BY) license (http://creativecommons.org/licenses/by/4.0/). 